\title{
DECISION SUPPORT SYSTEM REKOMENDASI PENERIMA \\ PROGRAM PEMERINTAH BANTUAN PANGAN NON TUNAI (BPNT) DENGAN MENGGUNAKAN METODE WEIGHTED PRODUCT (WP)
}

\author{
Arni Ayuning Tyas ${ }^{1)}$, Umi Chotijah' ${ }^{2)}$, Henny Dwi Bhakti ${ }^{3)}$ \\ ${ }^{1)}$ Desa Cerme Kidul \\ Jln. Raya Cerme Kidul No. 86. Kode Pos, : 61171 \\ ${ }^{2,3)}$ Universitas Muhammadiyah Gresik \\ Jl. Sumatera No. 101 GKB, Gresik. \\ e-mail: arniantyas@gmail.com ${ }^{1)}$,umi.chotijah@gmail.com²), hennydwi@umg.ac.id ${ }^{3)}$
}

\begin{abstract}
ABSTRAK
Dusun Cerme Kidul RT. 001 RW. 001, merupakan dusun yang terletak di Desa Cerme Kidul, Kecamatan Cerme, Kabupaten Gresik. Setiap dusun di desa cerme kidul akan mendapatkan program bantuan sosial dari pemerintah untuk meningkatkan taraf kehidupan warga dusun yang kurang mampu, salah satunya adalah Bantuan Pangan Non Tunai (BPNT). Dalam hal ini pihak kelurahan desa perlu mengidentifikasi warga dusun yang berhak direkomendasikan sebagai penerima bantuan sosial tersebut. Terdapat permasalahan dalam pelaksanaan rekomendasi tersebut, dimana pihak sekretaris desa akan menyeleksi sendiri dan kemungkinan terjadi kesalahan, seperti orang yang tidak berhak aakn direkomendasikan sedangkan yang berhak tidak direkomendasikan seagai penerima bantuan sosial. Maka dari itu proses rekomendasi penerma diperlukan SPK (Sistem Pendukung Keputusan) untuk menentukan warga dusun yang berhak direkomedasikan. Penelitian ini menggunakan metode Weighted Product (WP) untuk memberikan rekomendasi penerima program bantuan sosial. Penelitian ini menggunakan data warga dusun Cerme Kidul RT. 001 RW. 001 yang terdiri dari 95 data.
\end{abstract}

Kata Kunci: BPNT, Cerme, DSS, Rekomendasi, SPK, Weighted Product, WP .

\begin{abstract}
Cerme Kidul RT. 001 RW. 001, is a hamlet located in Cerme Kidul Village, Cerme District, Gresik Regency. Every hamlet in Cerme Kidul village will receive a social assistance program from the government to improve the living standards of the less fortunate hamlets, one of which is the Non-Cash Food Assistance (BPNT). In this case, the village kelurahan needs to identify the dusun residents who are entitled to be recommended as recipients of the social assistance. There are problems in implementing these recommendations, where the village secretary will self-select and errors may occur, such as people who are not entitled to be recommended while those who are entitled are not recommended as recipients of social assistance. Therefore, the recipient recommendation process requires an SPK (Decision Support System) to determine which hamlet residents are entitled to be recommended. This study uses the Weighted Product (WP) method to provide recommendations for recipients of social assistance programs. This study uses data from residents of Cerme Kidul RT. 001 RW. 001 which consists of 95 data.
\end{abstract}

Keywords: BPNT, Cerme, DSS, Rekommendation, SPK, Weighted Produc, WP .

\section{PENDAHULUAN}

$\mathrm{P}$ rogram Bantuan Pangan Non Tunai (BPNT) adalah bantuan sosial pangan dalam bentuk non tunai dari pemerintah yang diberikan kepada Keluarga Penerima Manfaat (KPM) yang memiliki Kartu Keluarga Sejahtera (KKS) setiap bulannya, melalui mekanisme akun elektronik yang digunakan hanya untuk membeli bahan pangan dipedagang bahan pangan yang sudah berkerja sama dengan bank (Irwan, 2019). Tujuan program bantuan sosial tersebut adalah untuk meningkatkan ketepatan kelompok sasaran, memberikan gizi yang lebih seimbang dan bervariasi, mendorong usaha eceran rakyat, dan diharapkan berdampak dalam peningkatan kesejahteraan dan kemampuan ekonomi KPM.

Penerima program BPNT di Dusun Cerme Kidul RT. 001 RW. 001, Kecamatan Cerme, Kabupaten Gresik merupakan warga desa yang didata dan diusulkan oleh ketua Rumah Tangga (RT). Kemudian daftar data tersebut akan diseleksi oleh sekretaris desa untuk menetukan rekomendasi penerima bantuan. Tapi karena seleksi yang dilakukan oleh sekretaris desa, terdapat kemungkinan rekomendasi penerima BPNT terjadi kesalahan dan tidak tepat sasaran. Dimana terdapat penerima yang tidak layak mendapat program BPNT malah mendapatkan dan sebaliknya yang seharusnya layak menjadi penerima malah tidak dapat.

Penentuan rekomendasi penerima BPNT di Dusun Cerme Kidul RT. 001 RW. 001 sangat dibutuhkan agar proses rekomendasi penerima BPNT akurat dan tepat sasaran. Skripsi yang dibuat dengan judul "Decision Support System Rekomendasi 
INDEXIA: Informatic and Computational Intelegent Journal

Arni Ayuning Tyas, Umi Chotijah, Henny Dwi Bhakti — Decision Support System Rekomendasi Penerima Program

Pemerintah Bantuan Pangan Non Tunai (BPNT) dengan Menggunakan Metode Weighted Product (Wp)

Penerima Program Pemerintah Bantuan Pangan Non Tunai (BPNT) dengan menggunakan Metode Weighted Product (WP)

(Studi Kasus : Dusun Cerme Kidul RT. 001 RW. 001, Kec. Cerme, Kab. Gresik)". Sistem ini akan menghasilkan output berupa pemeringkatan warga dusun, yang kemudian akan direkomendasikan sebagai penerima program bantuan. Kriteria yang digunakan untuk penilaian adalah usia, pendidikan, pekerjaan, penghasilan per bulan, jumlah tanggungan, status rumah, kendaraan, luas tanah, jenis lantai, jenis dinding, sumber air minum, sumber penerangan, dan fasilitas KMWC. Melalui Decision Support System ini diharapkan dapat memberikan kemudahan bagi sekretaris desa dalam merekomendasikan warga dusun penerima program BPNT secara cepat, akurat dan tepat sasaran.

\section{LANDASAN TEORI}

\subsection{Decision Support System (DSS)}

Pengertian Decision Support System (DSS) atau Sistem Pendukung Keputusan (SPK) merupakan sistem berbasis komputer, yang dapat mendukung pengambilan keputusan untuk menyelesaikan masalah yang semi terstruktur, dengan memanfaatkan data yang ada kemudian diolah menjadi suatu informasi berupa usulan menuju suatu kepuusan tertentu ${ }^{[1]}$.

Konsep Sistem Pendukung Keputusan (SPK) pertama kali diungkapkan pada awal tahun 1970-an oleh Michael S. Scott Morton dengan istilah Management Decision System yaitu suatu sistem yang berbasis komputer yang ditunjukan untuk membantu pengambil keputusan dengan memanfaatkan data dan model tertentu untuk memecahkan berbagai persoalan yang tidak terstruktur ${ }^{[9]}$.

\subsubsection{Karakteristik Decision Support System (DSS)}

Karakteristik dan kapabilitas Decision Support System (DSS) atau Sistem Pendukung Keputusan (SPK) diantaranya yaitu ${ }^{[8]}$ :

- SPK menyediakan dukungan bagi pengambil keputusan terutama pada situasi terstruktur dan tak terstruktur dengan memadukan pertimbangan manusia dan informasi terkomputerisasi.

- Dukungan untuk semua level manajerial, mulai dari eksekutif puncak sampai manajer lapangan.

- Dukungan untuk individu dan kelompok. Masalah yang kurang terstruktur sering memerlukan keterlibatan individu dari departemen dan tingkat organisasional yang berbeda atau bahkan dari organisasi lain.

- Dukungan untuk keputusan independen dan atau sekuensial. Keputusan dapat dibuat satu kali, beberapa kali atau berulang (dalam interval yang sama).

- Dukungan pada semua fase proses pengambilan keputusan : intelegensi, desain, pilihan dan implementasi.

\subsubsection{Tahapan Decision Support System (DSS)}

Tahapan-tahapan yang harus dilalui dalam proses DSS atau SPK sebagai berikut ${ }^{[2]}$ :

1. Tahap Pemahaman (Intelligence Phase)

Tahap ini merupakan proses penelusuran dan pendeteksian dari lingkup problematika serta proses pengenalan masalah. Data masukan diperoleh, diproses, dan diuji dalam rangka mengidentifikasikan masalah.

2. Tahap Perancangan (Design Phase)

Tahap ini merupakan proses pengembangan dan pencarian alternatif tindakan atau solusi yang dapat diambil. Tersebut merupakan representasi kejadian nyata yang disederhanakan, sehingga diperlukan proses validasi dan verifikasi untuk mengetahui keakuratan model dalam meneliti masalah yang ada.

3. Tahap Pemilihan (Choice Phase)

Pada tahap ini dilakukan pemilihan terhadap berbagai alternatif solusi yang dimunculkan pada tahap perencanaan agar ditentukan atau dengan memperhatikan kriteria-kriteria berdasarkan tujuan yang akan dicapai.

4. Tahap Implementasi (Implementation Phase)

Pada tahap ini dilakukan penerapan terhadap rancangan sistem yang telah dibuat pada tahap perancangan serta pelaksanaan alternatif tindakan yang telah dipilih pada tahap pemilihan.

\subsection{Bantuan Pangan Non Tunai (BPNT)}

Program Bantuan Pangan Non Tunai (BPNT) adalah bantuan sosial pangan dalam bentuk non tunai dari pemerintah yang diberikan kepada Keluarga Penerima Manfaat (KPM) yang memiliki Kartu Keluarga Sejahtera 
INDEXIA: Informatic and Computational Intelegent Journal

Arni Ayuning Tyas, Umi Chotijah, Henny Dwi Bhakti — Decision Support System Rekomendasi Penerima Program

Pemerintah Bantuan Pangan Non Tunai (BPNT) dengan Menggunakan Metode Weighted Product (Wp)

(KKS) setiap bulannya, melalui mekanisme akun elektronik yang digunakan hanya untuk membeli bahan pangan dipedagang bahan pangan yang sudah berkerja sama dengan bank ${ }^{[4]}$.

Manfaat dari program Bantuan Pangan Non Tunai (BPNT) yaitu meningkatkan ketahanan pangan di tingkat KPM sekaligus sebagai mekanisme perlindungan social dan penanggulangan kemiskinan, meningkatkan efisiensi penyaluran bantuan social, meningkatnya akses masyarakat terhadap layanan keuangan dan perbankan, meningkatkan transaksi nontunai dalam agenda Gerakan Nasional Nontunai (GNNT), dan meningkatkan pertumbuhan ekonomi di daerah, terutama usaha mikro dan kecil di bidang perdagangan ${ }^{[10]}$.

\subsection{Metode Weighted Product (WP)}

Metode WP merupakan suatu metode pengambilan keputusan multi-kriteria yang digunakan untuk menyelesaikan kasus yang mempunyai data dengan banyak atribut. Metode WP menggunakan perkalian untuk menghubungkan rating atribut, di mana rating setiap atribut harus dipangkatkan dahulu dengan bobot atribut yang bersangkutan. Metode WP banyak digunakan dalam sistem pengambilan keputusan dikarenakan metode ini mampu dalam pencarian solusi terbaik pada sistem perangkingan dengan proses perhitungan yang cukup mudah tanpa memerlukan waktu yang lama dalam perhitungan ${ }^{[5]}$.

\subsubsection{Tahapan Perhitungan Metode Weighted Product (WP)}

Tahapan-tahapan perhitungan penyelesaian masalah dengan menggunakan metode WP adalah sebagai berikut ${ }^{[5]}$ :

1. Penentuan kriteria dan menentukan besar bobot.

Penentuan kriteria untuk dijadikan dasar dalam penentuan dan menentukan besar bobot untuk masing-masing kriteria. Kriteria disimbolkan dengan $c_{i}$, di mana $i$ merupakan banyaknya kriteria yang ditentukan untuk dijadikan acuan dalam pengambilan keputusan.

2. Menentukan peringkat kecocokan untuk kriteria.

Menentukan nilai bobot awal (wo), kemudian membuat matriks keputusan dengan membuat peringkat kecocokan pada setiap kriteria.

3. Normalisasi bobot

Normalisasi bobot pada metode WP dilakukan dengan melakukan pembagian bobot setiap kriteria dengan jumlah keseluruhan bobot kriteria atau bisa disebut melakukan perhitungan nilai relatif bobot awal $(w j)$. Nilai total normalisasi bobot untuk seluruh kriteria harus memenuhi persamaan :

Keterangan :

$$
\sum_{j=1}^{n} w j=1
$$

$w=$ bobot kriteria

4. Menghitung nilai preferensi untuk alternatif sebagai vektor $S$

Nilai preferensi untuk alternatif dihitung dengan menggunakan persamaan :

Keterangan :

$$
S_{i}=\prod_{j=1}^{n} X_{i j}^{W j}
$$

$$
\begin{aligned}
& S=\text { preferensi alternative } \\
& w=\text { bobot kriteria } \\
& X=\text { nilai kriteria } \\
& i=\text { alternatif ke-i sampai dengan } \mathrm{n} \\
& j=\text { kriteria }
\end{aligned}
$$

Vektor $S$ dihitung dengan melakukan seluruh perkalian nilai kriteria 1 hingga $\mathrm{n}$ dengan memangkatkan $w$ sebagai bobot normalisasi tiap kriteria, yang akan bernilai positif apabila $w$ merupakan atribut keuntungan (benefit) dan bernilai negatif apabila $w$ merupakan atribut biaya (cost).

5. Menghitung nilai preferensi relatif sebagai vektor $V$

Vektor $V$ merupakan nilai preferensi relatif yang akan digunakan untuk mencari peringkat dari hasil perhitungan setiap alternatif.

$$
V_{i}=\frac{S_{i}}{\prod_{j=1}^{n}\left(X_{j}\right)^{w j}}
$$


INDEXIA: Informatic and Computational Intelegent Journal

Arni Ayuning Tyas, Umi Chotijah, Henny Dwi Bhakti — Decision Support System Rekomendasi Penerima Program

Pemerintah Bantuan Pangan Non Tunai (BPNT) dengan Menggunakan Metode Weighted Product (Wp)

6. Membuat peringkat nilai vector $\mathrm{V}$

Pada tahap ini akan diketahui alternatif yang memiliki nilai Vi tertinggi yang merupakan hasil dari keputusan.

\section{ANALISIS DAN PERANCANGAN SISTEM}

\subsection{Analisis}

Proses penentuan warga dusun sebagai penerima program pemerintah BPNT di dusun Cerme Kidul RT.001 RW.001 dilakukan dengan pengajuan data warga dusun oleh ketua RT ke sekretaris desa. Kemudian daftar data tersebut akan diseleksi oleh sekretaris desa untuk menetukan rekomendasi penerima bantuan. Tapi karena seleksi yang dilakukan oleh sekretaris desa, terdapat kemungkinan rekomendasi penerima BPNT terjadi kesalahan dan tidak tepat sasaran. Dimana terdapat penerima yang tidak layak mendapat bantuan sosial malah mendapatkan BPNT dan sebaliknya yang seharusnya layak menjadi penerima malah tidak dapat. Kriteriakriteria tersebut berupa usia, pendidikan, pekerjaan, penghasilan per bulan, jumlah tanggungan, status rumah, kendaraan, luas tanah, jenis lantai, jenis dinding, sumber air minum, sumber penerangan, dan fasilitas KMWC. Dari analisis permasalahan tersebut maka diperlukan adanya penerapan SPK rekomendasi penerima program pemerintah BPNT di Cerme Kidul RT.001 RW.001 yang akan membantu pihak sekretaris desa dalam menentukan rekomedasi warga dusun penerima BPNT.

\subsection{Hasil Analisis}

Hasil analisis penentuan warga dusun penerima program pemerintah BPNT di dusun Cerme Kidul RT.001 RW.001 dalam menyelesaikan permasalahan rekomendasi calon penerima bantuan sosial BPNT dengan tepat sasaran, maka dibutuhkan peran sebuah sistem pengambilan keputusan rekomendasi penerima program pemerintah BPNT yang dapat membantu dan memudahkan pihak sekretaris desa dalam menyeleksi dan merekomendasikan penerima program pemerintah BPNT tersebut sesuai dengan kriteria-kriteria yang ditentukan secara cepat, akurat dan tepat sasaran.

Sistem rekomendasi calon penerima bantuan sosial ini akan menyimpan data warga desa, tapi hanya 1 (satu) perwakilan dari setiap 1 (satu) Kartu Keluarga. Data tersebut meliputi nama, usia, pendidikan, pekerjaan, penghasilan per bulan, jumlah tanggungan, status rumah, kendaraan, luas tanah, jenis lantai, jenis dinding, sumber air minum, sumber penerangan, dan fasilitas KMWC. Kemudian tiap kriteria kecuali nama akan dikelompokkan menjadi benefit atau cost dan ditentukan rating kepentingan atau bobot kepentingan oleh sekretaris desa. Selanjutnya data-data tersebut akan dilakukan perhitungan dengan metode WP.

Sistem ini menghasilkan nilai akhir vektor $V$, kemudian nilai tersebut akan diperingkatkan berdasarkan nilai terbesar ke terkecil. Hasil pemeringkatan tersebut akan dijadikan dasar rekomendasi warga dusun penerima program pemerintah BPNT. Data warga dusun yang akan direkomendasi merupakan data dengan peringkat tertinggi ke 1 sampai 25.

Tabel 3.1 Kebutuhan Stackholder

\begin{tabular}{|c|c|c|c|c|}
\hline No & Entitas & Informasi & Proses & Data \\
\hline 1. & $\begin{array}{c}\text { Admin } \\
\text { (Sekretaris } \\
\text { Desa) }\end{array}$ & $\begin{array}{ll}\text { Mendapatkan } & \text { hasil } \\
\text { akhir vektor v yang } \\
\text { dijadikan dasar } \\
\text { pemeringkatan }\end{array}$ & $\begin{array}{l}\text { Proses pemasukkan } \\
\text { data } \\
\text { Proses penilaian }\end{array}$ & $\begin{array}{l}\text { Melakukan in- } \\
\text { put data warga } \\
\text { dusun } \\
\text { Input nilai } \\
\text { bobot } \\
\text { kepentingan }\end{array}$ \\
\hline
\end{tabular}

\subsection{Representasi Model}

Data yang digunakan dalam penelitian ini berasal dari pengisian angket oleh warga dusun Cerme Kidul RT.001 RW.001 pada tahun 2021 dengan total 95 data perwakilan 1 (satu) orang dari 1 (satu) KK. Metode WP merupakan metode yang digunakan dalam menyelesaikan permasalahan yang ada di dusun Cerme Kidul RT.001 RW.001 untuk memberikan rekomendasi calon penerima bantuan sosial pemerintah BPNT dengan menggunakan kriteria berupa usia, pendidikan, pekerjaan, penghasilan per bulan, jumlah tanggungan, status rumah, kendaraan, luas tanah, jenis lantai, jenis dinding, sumber air minum, sumber penerangan, dan fasilitas KMWC. Lebih jelas tentang kriteria yang digunakan dalam mengambil keputusan dapat dilihat pada tabel 3.2. 
INDEXIA: Informatic and Computational Intelegent Journal

Arni Ayuning Tyas, Umi Chotijah, Henny Dwi Bhakti — Decision Support System Rekomendasi Penerima Program

Pemerintah Bantuan Pangan Non Tunai (BPNT) dengan Menggunakan Metode Weighted Product (Wp)

Tingkat kepentingan bobot dibutuhkan juga untuk menentukan nilai normalisasi bobot pada setiap kriteria, keterangan nilai bobot terdapat pada tabel 3.3.

Tabel 3.2 Tabel Kriteria

\begin{tabular}{|c|l|c|c|c|}
\hline $\begin{array}{c}\text { Kode } \\
\text { Kriteria }\end{array}$ & Nama Kriteria & Atribut & Bobot & $\begin{array}{c}\text { Normalisasi } \\
\text { Bobot }\end{array}$ \\
\hline C1 & Usia & Benefit & 4 & 0,100 \\
\hline C2 & Pendidikan & Benefit & 3 & 0,075 \\
\hline C3 & Pekerjaan & Benefit & 5 & 0,125 \\
\hline C4 & $\begin{array}{l}\text { Penghasilan per } \\
\text { bulan }\end{array}$ & Cost & 5 & 0,125 \\
\hline C5 & $\begin{array}{l}\text { Jumlah } \\
\text { tanggungan }\end{array}$ & Cost & 4 & 0,100 \\
\hline C6 & Kendaraan & Benefit & 3 & 0,075 \\
\hline C7 & Status rumah & Benefit & 2 & 0,050 \\
\hline C8 & Luas tanah & Cost & 2 & 0,050 \\
\hline C9 & Jenis lantai & Benefit & 2 & 0,050 \\
\hline C10 & Jenis dinding & Benefit & 2 & 0,050 \\
\hline C11 & $\begin{array}{l}\text { Sumber air } \\
\text { minum }\end{array}$ & Benefit & 3 & 0,075 \\
\hline C12 & $\begin{array}{l}\text { Sumber } \\
\text { penerangan }\end{array}$ & Benefit & 3 & 0,075 \\
\hline C13 & Fasilitas KMWC & Benefit & 2 & 0,050 \\
\hline & \multicolumn{2}{|c}{ Total } & 40 & 1,000 \\
\hline
\end{tabular}

Tabel 3.3 Tabel Tingkat Kepentingan Kriteria Bobot

\begin{tabular}{|c|l|}
\hline Nilai Bobot & \multicolumn{1}{|c|}{ Keterangan Kepentingan } \\
\hline 1 & Tidak Penting \\
\hline 2 & Kurang Penting \\
\hline 3 & Cukup Penting \\
\hline 4 & Penting \\
\hline 5 & Sangat Penting \\
\hline
\end{tabular}

Bobot kriteria menentukan seberapa penting kriteria tersebut, atribut kriteria terdiri dari benefit atau cost, dimana semakin besar nilainya maka semakin bagus dan sedangkan cost semakin kecil nilainya maka semakin bagus. Dan diambil 15 (lima belas) data sampel dari total 95 data hasil penyebaran angket dari warga dusun Cerme Kidul RT.001 RW.001 telah dikelompokan berdasarkan kriteria diatas disajikan dalam tabel 3.4.

Tabel 3.4 Data Angket Warga Dusun Cerme Kidul RT.001 RW.001

\begin{tabular}{|c|c|c|c|c|c|c|c|c|c|c|c|c|c|c|}
\hline \multirow[b]{2}{*}{ No } & \multirow[b]{2}{*}{ Nama } & \multicolumn{13}{|c|}{ Kriteria } \\
\hline & & Usia & $\begin{array}{l}\text { Pendi- } \\
\text { dikan }\end{array}$ & Pekerjaan & Penghasilan & $\begin{array}{l}\text { Tang- } \\
\text { gungan }\end{array}$ & $\begin{array}{l}\text { Kenda- } \\
\text { raan }\end{array}$ & $\begin{array}{l}\text { Status } \\
\text { Rumah }\end{array}$ & $\begin{array}{c}\text { Luas } \\
\text { Tanah }\end{array}$ & $\begin{array}{c}\text { Jenis } \\
\text { Lantai }\end{array}$ & $\begin{array}{c}\text { Jenis } \\
\text { Dinding }\end{array}$ & $\begin{array}{c}\text { Smb. Air } \\
\text { Minum }\end{array}$ & $\begin{array}{c}\text { Smb. } \\
\text { Penerangan }\end{array}$ & $\begin{array}{c}\text { Fasilitas } \\
\text { KMCWC }\end{array}$ \\
\hline 1 & Hariyanto & 47 & SMA & Pengusaha & $\begin{array}{c}1.500 .000- \\
3.000 .000\end{array}$ & $2-3$ & $\begin{array}{l}\text { Sepeda } \\
\text { Motor }\end{array}$ & $\begin{array}{c}\text { Milik } \\
\text { Sendiri }\end{array}$ & $\begin{array}{l}>8 \\
\text { M2 }\end{array}$ & Kramik & Tembok & Isi Ulang & $\begin{array}{l}\text { PLN Non } \\
\text { Subsidi }\end{array}$ & Sendiri \\
\hline 2 & $\begin{array}{l}\text { Hariyadi } \\
\text { Santoso }\end{array}$ & 52 & SMA & Karyawan & $\begin{array}{c}1.500 .000- \\
3.000 .000\end{array}$ & $2-3$ & $\begin{array}{l}\text { Sepeda } \\
\text { Motor }\end{array}$ & Kontrak & $\begin{array}{l}<8 \\
\text { M2 } \\
\end{array}$ & Semen & Kayu & Sumur & $\begin{array}{l}\text { PLN Non } \\
\text { Subsidi }\end{array}$ & Sendiri \\
\hline 3 & Makmur & 65 & SD & $\begin{array}{c}\text { Tidak } \\
\text { Bekerja }\end{array}$ & $<500.000$ & $2-3$ & $\begin{array}{l}\text { Sepeda } \\
\text { Motor }\end{array}$ & $\begin{array}{c}\text { Milik } \\
\text { Sendiri }\end{array}$ & $\begin{array}{l}>8 \\
\text { M2 }\end{array}$ & Kramik & Kayu & Sumur & $\begin{array}{c}\text { PLN } \\
\text { Subsidi }\end{array}$ & Sendiri \\
\hline 4 & $\begin{array}{l}\text { M. Ilham } \\
\text { Ghozali }\end{array}$ & 38 & SMA & Karyawan & $>3.000 .000$ & $>4$ & Mobil & $\begin{array}{c}\text { Milik } \\
\text { Sendiri }\end{array}$ & $\begin{array}{l}>8 \\
\text { M2 }\end{array}$ & Kramik & Tembok & Ladeng/Pipa & $\begin{array}{c}\text { PLN } \\
\text { Subsidi }\end{array}$ & Sendiri \\
\hline 5 & $\begin{array}{l}\text { Mohamad } \\
\text { Dirham }\end{array}$ & 47 & SMA & Karyawan & $\begin{array}{l}1.500 .000- \\
3.000 .000\end{array}$ & $2-3$ & $\begin{array}{l}\text { Sepeda } \\
\text { Motor }\end{array}$ & $\begin{array}{c}\text { Milik } \\
\text { Sendiri }\end{array}$ & $\begin{array}{l}>8 \\
\text { M2 }\end{array}$ & Kramik & Tembok & Isi Ulang & $\begin{array}{c}\text { PLN } \\
\text { Subsidi }\end{array}$ & Sendiri \\
\hline 6 & Ribut & 51 & PT & Karyawan & $>3.000 .000$ & $2-3$ & Mobil & $\begin{array}{c}\text { Milik } \\
\text { Sendiri }\end{array}$ & $\begin{array}{l}>8 \\
\text { M2 }\end{array}$ & Kramik & Tembok & Isi Ulang & $\begin{array}{l}\text { PLN Non } \\
\text { Subsidi }\end{array}$ & Sendiri \\
\hline 7 & $\begin{array}{l}\text { Satria Rio } \\
\text { D. }\end{array}$ & 25 & PT & Karyawan & $>3.000 .000$ & 1 & Mobil & $\begin{array}{c}\text { Milik } \\
\text { Orang } \\
\text { Tua }\end{array}$ & $\begin{array}{l}>8 \\
\text { M2 }\end{array}$ & Kramik & Tembok & Isi Ulang & $\begin{array}{l}\text { PLN Non } \\
\text { Subsidi }\end{array}$ & Sendiri \\
\hline 8 & Sarwi & 52 & SMA & Pedagang & $>3.000 .000$ & $2-3$ & Mobil & $\begin{array}{c}\text { Milik } \\
\text { Sendiri }\end{array}$ & $\begin{array}{l}>8 \\
\text { M2 }\end{array}$ & Kramik & Tembok & Isi Ulang & $\begin{array}{c}\text { PLN Non } \\
\text { Subsidi }\end{array}$ & Sendiri \\
\hline 9 & Sugiantoro & 54 & SMA & Karyawan & $>3.000 .000$ & $2-3$ & Mobil & $\begin{array}{c}\text { Milik } \\
\text { Sendiri }\end{array}$ & $\begin{array}{l}>8 \\
\text { M2 }\end{array}$ & Kramik & Tembok & Isi Ulang & $\begin{array}{l}\text { PLN Non } \\
\text { Subsidi }\end{array}$ & Sendiri \\
\hline 10 & Suriani & 56 & SMA & $\begin{array}{c}\text { Tidak } \\
\text { Bekerja }\end{array}$ & $<500.000$ & $2-3$ & $\begin{array}{l}\text { Sepeda } \\
\text { Motor }\end{array}$ & $\begin{array}{c}\text { Milik } \\
\text { Orang } \\
\text { Tua }\end{array}$ & $\begin{array}{l}>8 \\
\text { M2 }\end{array}$ & Kramik & Tembok & Sumur & $\begin{array}{l}\text { PLN } \\
\text { Subsidi }\end{array}$ & Sendiri \\
\hline 11 & Suroso & 58 & PT & Karyawan & $>3.000 .000$ & $2-3$ & Mobil & $\begin{array}{c}\text { Milik } \\
\text { Sendiri }\end{array}$ & $\begin{array}{l}>8 \\
\text { M2 }\end{array}$ & Kramik & Tembok & Isi Ulang & $\begin{array}{l}\text { PLN Non } \\
\text { Subsidi }\end{array}$ & Sendiri \\
\hline 12 & $\begin{array}{l}\text { Toto } \\
\text { Suryadi }\end{array}$ & 51 & SMA & Karyawan & $>3.000 .000$ & $>4$ & $\begin{array}{l}\text { Sepeda } \\
\text { Motor }\end{array}$ & $\begin{array}{c}\text { Milik } \\
\text { Sendiri }\end{array}$ & $\begin{array}{l}>8 \\
\text { M2 }\end{array}$ & Kramik & Tembok & Isi Ulang & $\begin{array}{l}\text { PLN } \\
\text { Subsidi }\end{array}$ & Sendiri \\
\hline 13 & $\begin{array}{l}\text { Tri } \\
\text { Hartanto }\end{array}$ & 47 & SMA & Karyawan & $>3.000 .000$ & $2-3$ & $\begin{array}{l}\text { Sepeda } \\
\text { Motor }\end{array}$ & $\begin{array}{c}\text { Milik } \\
\text { Sendiri }\end{array}$ & $\begin{array}{l}>8 \\
\text { M2 }\end{array}$ & Kramik & Tembok & Isi Ulang & $\begin{array}{l}\text { PLN Non } \\
\text { Subsidi }\end{array}$ & Sendiri \\
\hline 14 & Faisol & 56 & SMA & $\begin{array}{c}\text { Tidak } \\
\text { Bekerja }\end{array}$ & $<500.000$ & $2-3$ & $\begin{array}{l}\text { Sepeda } \\
\text { Motor }\end{array}$ & $\begin{array}{c}\text { Milik } \\
\text { Sendiri }\end{array}$ & $\begin{array}{l}>8 \\
\text { M2 }\end{array}$ & Kramik & Tembok & Ladeng/Pipa & $\begin{array}{c}\text { PLN } \\
\text { Subsidi }\end{array}$ & Sendiri \\
\hline 15 & Salehudin & 60 & SMA & Karyawan & $>3.000 .000$ & $2-3$ & Mobil & $\begin{array}{c}\text { Milik } \\
\text { Sendiri }\end{array}$ & $\begin{array}{l}>8 \\
\text { M2 }\end{array}$ & Kramik & Tembok & Isi Ulang & $\begin{array}{c}\text { PLN Non } \\
\text { Subsidi }\end{array}$ & Sendiri \\
\hline
\end{tabular}


INDEXIA: Informatic and Computational Intelegent Journal

Arni Ayuning Tyas, Umi Chotijah, Henny Dwi Bhakti — Decision Support System Rekomendasi Penerima Program

Pemerintah Bantuan Pangan Non Tunai (BPNT) dengan Menggunakan Metode Weighted Product (Wp)

Data yang digunankan dalam perhitungan proses rekomendasi penerima program pemerintah BPNT adalah data yang terdapat pada tabel 3.2 dan tabel 3.3. Berikut akan disajikan proses perhitungan metode WP menggunakan data tersebut. Langkah - Langkah pendukung keputusan dengan metode WP adalah sebagai berikut.

1. Menentukan nilai bobot pada masing-masing kriteria

Kriteria yang digunakan dalam penelitian sudah ditentukan oleh kelurahan desa atau lebih tepatnya pihak sekretaris desa Cerme Kidul. Nilai bobot untuk kategori kriteria yang digunakan adalah sebagai berikut.

a. Nilai bobot untuk kriteria usia

Tabel 3.5 Nilai Kriteria Usia

\begin{tabular}{|c|l|c|}
\hline Usia & \multicolumn{1}{|c|}{ Kategori } & Nilai \\
\hline $17-26$ & Kurang & 1 \\
\hline $27-39$ & Cukup & 2 \\
\hline $40-50$ & Memenuhi & 3 \\
\hline $51-65$ & Sangat Memenuhi & 4 \\
\hline
\end{tabular}

b. Nilai bobot untuk kriteria pendidikan

Tabel 3.6 Nilai Kriteria Pendidikan

\begin{tabular}{|l|l|c|}
\hline \multicolumn{1}{|c|}{ Pendidikan } & \multicolumn{1}{c|}{ Kategori } & Nilai \\
\hline Perguruan Tinggi & Kurang & 1 \\
\hline SMA & Cukup & 2 \\
\hline SMP & Memenuhi & 3 \\
\hline Sekolah Dasar & Sangat Memenuhi & 4 \\
\hline
\end{tabular}

c. Nilai bobot untuk kriteria pekerjaan

Tabel 3.7 Nilai Kriteria Pekerjaan

\begin{tabular}{|l|l|c|}
\hline \multicolumn{1}{|c|}{ Pekerjaan } & \multicolumn{1}{c|}{ Kategori } & Nilai \\
\hline Karyawan & Kurang & 1 \\
\hline Pedagang/Pengusaha & Cukup & 2 \\
\hline Serabutan/Petani & Memenuhi & 3 \\
\hline Tidak Bekerja & Sangat Memenuhi & 4 \\
\hline
\end{tabular}

d. Nilai bobot untuk kriteria Pendapatan

Tabel 3.8 Nilai Kriteria Pendapatan

\begin{tabular}{|l|l|c|}
\multicolumn{1}{|c|}{ Pendapatan } & \multicolumn{1}{c|}{ Kategori } & Nilai \\
\hline$\leq$ Rp. 300.0000 & Sangat Memenuhi & 1 \\
\hline Rp. $300.000-$ Rp. 1.300 .000 & Memenuhi & 2 \\
\hline Rp. $1.300 .000-$ Rp. 3.000.000 & Cukup & 3 \\
\hline$\geq$ Rp. 3.000.000 & Kurang & 4 \\
\hline
\end{tabular}

e. Nilai bobot untuk kriteria tanggungan

Tabel 3.9 Nilai Kriteria Tanggungan

\begin{tabular}{|l|l|c|}
\hline \multicolumn{1}{|c|}{ Tanggungan } & \multicolumn{1}{c|}{ Kategori } & Nilai \\
\hline 1 & Cukup & 1 \\
\hline $2-3$ & Memenuhi & 2 \\
\hline$>4$ & Sangat Memenuhi & 3 \\
\hline
\end{tabular}

f. Nilai bobot untuk kriteria kendaraan

Tabel 3.10 Nilai Kriteria Kendaraan

\begin{tabular}{|l|l|c|}
\hline \multicolumn{1}{|c|}{ Kendaraan } & \multicolumn{1}{c|}{ Kategori } & Nilai \\
\hline Mobil & Kurang & 1 \\
\hline Sepeda Motor & Cukup & 2 \\
\hline Sepeda & Memenuhi & 3 \\
\hline Tidak Punya & Sangat Memenuhi & 4 \\
\hline
\end{tabular}

g. Nilai bobot untuk kriteria status rumah 
INDEXIA: Informatic and Computational Intelegent Journal

Arni Ayuning Tyas, Umi Chotijah, Henny Dwi Bhakti — Decision Support System Rekomendasi Penerima Program

Pemerintah Bantuan Pangan Non Tunai (BPNT) dengan Menggunakan Metode Weighted Product (Wp)

Tabel 3.11 Nilai Kriteria Status Rumah

\begin{tabular}{|l|l|c|}
\hline \multicolumn{1}{|c|}{ Status Rumah } & \multicolumn{1}{c|}{ Kategori } & Nilai \\
\hline Milik Sendiri & Kurang & 1 \\
\hline Milik Oranng Tua & Cukup & 2 \\
\hline Kontrak & Memenuhi & 3 \\
\hline Bebas Sewa & Sangat Memenuhi & 4 \\
\hline
\end{tabular}

h. Nilai bobot untuk kriteria luas tanah

Tabel 3.12 Nilai Kriteria Luas Tanah

\begin{tabular}{|l|l|c|}
\hline \multicolumn{1}{|c|}{ Luas Tanah } & \multicolumn{1}{|c|}{ Kategori } & Nilai \\
\hline$<8 \mathrm{M} 2$ & Memenuhi & 1 \\
\hline$>8 \mathrm{M} 2$ & Kurang & 2 \\
\hline
\end{tabular}

i. Nilai bobot untuk kriteria jenis lantai

Tabel 3.13 Nilai Kriteria Jenis Lantai

\begin{tabular}{|l|l|c|}
\hline \multicolumn{1}{|c|}{ Jenis Lantai } & \multicolumn{1}{c|}{ Kategori } & Nilai \\
\hline Kramik & Kurang & 1 \\
\hline Semen & Cukup & 2 \\
\hline Tanah & Memenuhi & 3 \\
\hline
\end{tabular}

j. $\quad$ Nilai bobot untuk kriteria jenis dinding

Tabel 3.14 Nilai Kriteria Jenis Dinding

\begin{tabular}{|l|l|c|}
\hline \multicolumn{1}{|c|}{ Jenis Dinding } & \multicolumn{1}{c|}{ Kategori } & Nilai \\
\hline Tembok & Kurang & 1 \\
\hline Kayu & Cukup & 2 \\
\hline Bambu & Memenuhi & 3 \\
\hline
\end{tabular}

k. Nilai bobot untuk kriteria sumber air minum

Tabel 3.15 Nilai Kriteria Sumber Air Minum

\begin{tabular}{|l|l|c|}
\hline \multicolumn{1}{|c|}{ Sumber Air Minum } & \multicolumn{1}{c|}{ Kategori } & Nilai \\
\hline Isi Ulang & Kurang & 1 \\
\hline Ladeng/Pipa & Cukup & 2 \\
\hline Sumur & Memenuhi & 3 \\
\hline Sungai & Sangat Memenuhi & 4 \\
\hline
\end{tabular}

1. Nilai bobot untuk kriteria sumber penerangan

Tabel 3.16 Nilai Kriteria Sumber Penerangan

\begin{tabular}{|l|l|c|}
\hline \multicolumn{1}{|c|}{ Sumber Penerangan } & \multicolumn{1}{|c|}{ Kategori } & Nilai \\
\hline PLN Non Subsidi & Kurang & 1 \\
\hline PLN Subsiid & Cukup & 2 \\
\hline Tidak Ada & Memenuhi & 3 \\
\hline
\end{tabular}

m. Nilai bobot untuk kriteria fasilitas KMWC

Tabel 3.17 Nilai Kriteria Fasilitas KMWC

\begin{tabular}{|l|l|c|}
\hline \multicolumn{1}{|c|}{ Fasilitas KMWC } & \multicolumn{1}{|c|}{ Kategori } & Nilai \\
\hline Sendiri & Kurang & 1 \\
\hline Umum & Cukup & 2 \\
\hline Tidak Ada & Memenuhi & 3 \\
\hline
\end{tabular}

2. Menentukan nilai tingkat kepentingan pada masing-masing kriteria

Nilai tingkat kepentingan bobot kriteria untuk menentuka mana yang lebih diutamakan terdapat pada tabel 3.2 dengan keterangan nilai terdapat pada tabel 3.3. Berikutnya adalah menentukan jenis tiap kriteria, yaitu termasuk kriteria benefit atau cost. Penentuan ini berdasarka informasi :

a) Benefit : Jenis kriteria jika nilai semakin besar maka semakin baik atau penting, jika semakin kecil maka bernilai tidak baik atau tidak penting. 
INDEXIA: Informatic and Computational Intelegent Journal

Arni Ayuning Tyas, Umi Chotijah, Henny Dwi Bhakti — Decision Support System Rekomendasi Penerima Program

Pemerintah Bantuan Pangan Non Tunai (BPNT) dengan Menggunakan Metode Weighted Product (Wp)

b) Cost : Jenis kriteria jika nilai semakin kecil maka semakin baik atau lebih penting, jika semakin besar maka bernilai atau tidak terlalu penting.

3. Menghitung normalisasi bobot atau nilai relatif bobot awal (wj)

Perhitungan normalisasi bobot pada metode WP dilakukan dengan mengitung total nilai bobot kemudian dibagi dengan nilai bobot masing-masing kriteria, dimana total normalisasi bobot harus berjumlah 1 (satu).

Data kriteria ada di tabel 3.2.

a. Normalisasi Bobot Kriteria Usia

$w j=\left(\frac{4}{40}\right)=0,100$

b. Normalisasi Bobot Kriteria Pendidikan

$w j=\left(\frac{3}{40}\right)=0,075$

c. Normalisasi Bobot Kriteria Pekerjaan

$w j=\left(\frac{5}{40}\right)=0,125$

d. Normalisasi Bobot Kriteria Pendapatan

$w j=\left(\frac{5}{40}\right)=0,125$

e. Normalisasi Bobot Kriteria Jumlah Tanggungan

$w j=\left(\frac{4}{40}\right)=0,100$

f. Normalisasi Bobot Kriteria Kendaraan

$w j=\left(\frac{3}{40}\right)=0,075$

g. Normalisasi Bobot Kriteria Status Rumah

$w j=\left(\frac{2}{40}\right)=0,050$

h. Normalisasi Bobot Kriteria Luas Tanah

$w j=\left(\frac{2}{40}\right)=0,050$

i. Normalisasi Bobot Kriteria Jenis Lantai

$w j=\left(\frac{2}{40}\right)=0,050$

j. Normalisasi Bobot Kriteria Jenis Dinding

$w j=\left(\frac{2}{40}\right)=0,050$

k. Normalisasi Bobot Kriteria Sumber Air Minum

$w j=\left(\frac{3}{40}\right)=0,075$

1. Normalisasi Bobot Kriteria Sumber Penerangan

$w j=\left(\frac{3}{40}\right)=0,075$

m. Normalisasi Bobot Kriteria Fasilitas KMWC

$w j=\left(\frac{2}{40}\right)=0,050$

4. Menentukan alternatif

Data nama warga dusun Cerme Kidul RT.001 RW.001 dan kriteria-kriteria yang digunakan dalam perankingan calon penerima bantuan dengan menggunakan metode $W P$ terdapat dalam tabel 3.4 dan tabel 3.2. Daftar nama warga dusun tersebut akan diwakili dengan data alternatif dari A1 sampai dengan A15. Sedangkan data kriteria-kriteria akan diwakilkan data alternatif C1 sampai C13.

Tabel 3.18 Data Alternatif Warga Dusun dan Kriteria

\begin{tabular}{|c|c|c|}
\hline \multirow{2}{*}{ No. } & \multicolumn{2}{|c|}{ Alternatif } \\
\cline { 2 - 3 } & Warga Dusun & Kriteria \\
\hline 1 & A1 & C1 \\
\hline 2 & A2 & C2 \\
\hline 3 & A3 & C 3 \\
\hline
\end{tabular}


INDEXIA: Informatic and Computational Intelegent Journal

Arni Ayuning Tyas, Umi Chotijah, Henny Dwi Bhakti — Decision Support System Rekomendasi Penerima Program

Pemerintah Bantuan Pangan Non Tunai (BPNT) dengan Menggunakan Metode Weighted Product (Wp)

\begin{tabular}{|c|c|c|}
\hline 4 & A4 & C4 \\
\hline 5 & A5 & C5 \\
\hline 6 & A6 & C6 \\
\hline 7 & A7 & C7 \\
\hline 8 & A8 & C8 \\
\hline 9 & A9 & C9 \\
\hline 10 & A10 & C10 \\
\hline 11 & A11 & C11 \\
\hline 12 & A12 & C12 \\
\hline 13 & A13 & C13 \\
\hline 14 & A14 & \\
\hline 15 & A15 & \\
\hline
\end{tabular}

5. Memasukkan nilai bobot kriteria pada tiap alternatif

Pada tahap ini akan dilakukan penginputan nilai bobot kriteria ke masing masing alternatif.

Tabel 3.19 Input Nilai Bobot Kriteria

\begin{tabular}{|l|c|c|c|c|c|c|c|c|c|c|c|c|c|}
\hline \multirow{2}{*}{ WD } & \multicolumn{10}{|c|}{ KRITERIA } \\
\cline { 2 - 16 } & C1 & C2 & C3 & C4 & C5 & C6 & C7 & C8 & C9 & C10 & C11 & C12 & C13 \\
\hline A1 & 3 & 2 & 2 & 3 & 2 & 2 & 1 & 2 & 1 & 1 & 1 & 1 & 1 \\
\hline A2 & 4 & 2 & 1 & 3 & 2 & 2 & 3 & 1 & 2 & 2 & 3 & 1 & 1 \\
\hline A3 & 4 & 4 & 4 & 1 & 2 & 2 & 1 & 2 & 1 & 2 & 3 & 2 & 1 \\
\hline A4 & 2 & 2 & 1 & 4 & 1 & 1 & 1 & 2 & 1 & 1 & 2 & 2 & 1 \\
\hline A5 & 3 & 2 & 1 & 3 & 2 & 2 & 1 & 2 & 1 & 1 & 1 & 2 & 1 \\
\hline A6 & 4 & 1 & 1 & 4 & 2 & 1 & 1 & 2 & 1 & 1 & 1 & 1 & 1 \\
\hline A7 & 1 & 1 & 1 & 4 & 3 & 1 & 2 & 2 & 1 & 1 & 1 & 1 & 1 \\
\hline A8 & 4 & 2 & 2 & 4 & 2 & 1 & 1 & 2 & 1 & 1 & 1 & 1 & 1 \\
\hline A9 & 4 & 2 & 1 & 4 & 2 & 1 & 1 & 2 & 1 & 1 & 1 & 1 & 1 \\
\hline A10 & 4 & 2 & 4 & 1 & 2 & 2 & 2 & 2 & 1 & 1 & 3 & 2 & 1 \\
\hline A11 & 4 & 1 & 1 & 4 & 2 & 1 & 1 & 2 & 1 & 1 & 1 & 1 & 1 \\
\hline A12 & 4 & 2 & 1 & 4 & 1 & 2 & 1 & 2 & 1 & 1 & 1 & 2 & 1 \\
\hline A13 & 3 & 2 & 1 & 4 & 2 & 2 & 1 & 2 & 1 & 1 & 1 & 1 & 1 \\
\hline A14 & 4 & 2 & 4 & 1 & 2 & 2 & 1 & 2 & 1 & 1 & 2 & 2 & 1 \\
\hline A15 & 4 & 2 & 1 & 4 & 2 & 1 & 1 & 2 & 1 & 1 & 1 & 1 & 1 \\
\hline
\end{tabular}

6. Menentukan pangkat bobot kriteria awal

Menentukan pangkat bobot kriteria awal dibutuhkan untuk mencari proses perhitungan selanjutnya yaitu nilai relatif preferensi vektor $S$. Cara menentukanya jika kriteria masuk kategori benefit maka nilai hasil normalisasi bobot akan dikali 1 (satu), dan sebaliknya jika masuk kategori cost maka akan dikali dengan - 1 (minus satu).

Tabel 3.20 Pangkat Bobot Kriteria Awal

\begin{tabular}{|c|c|c|c|}
\hline $\begin{array}{c}\text { Kode } \\
\text { Kriteria }\end{array}$ & Atribut & $\begin{array}{c}\text { Normalisasi } \\
\text { Bobot }\end{array}$ & Pangkat \\
\hline C1 & Benefit & 0,100 & 0,100 \\
\hline C2 & Benefit & 0,075 & 0,075 \\
\hline C3 & Benefit & 0,125 & 0,125 \\
\hline C4 & Cost & 0,125 & $-0,125$ \\
\hline C5 & Cost & 0,100 & $-0,100$ \\
\hline C6 & Benefit & 0,075 & 0,075 \\
\hline C7 & Benefit & 0,050 & 0,050 \\
\hline C8 & Cost & 0,050 & $-0,050$ \\
\hline C9 & Benefit & 0,050 & 0,050 \\
\hline C10 & Benefit & 0,050 & 0,050 \\
\hline C11 & Benefit & 0,075 & 0,075 \\
\hline
\end{tabular}


INDEXIA: Informatic and Computational Intelegent Journal

Arni Ayuning Tyas, Umi Chotijah, Henny Dwi Bhakti — Decision Support System Rekomendasi Penerima Program

Pemerintah Bantuan Pangan Non Tunai (BPNT) dengan Menggunakan Metode Weighted Product (Wp)

\begin{tabular}{|l|l|l|l|}
$\mathrm{C} 12$ & Benefit & 0,075 & 0,075 \\
\hline $\mathrm{C} 13$ & Benefit & 0,050 & 0,050 \\
\hline
\end{tabular}


INDEXIA: Informatic and Computational Intelegent Journal

Arni Ayuning Tyas, Umi Chotijah, Henny Dwi Bhakti — Decision Support System Rekomendasi Penerima Program

Pemerintah Bantuan Pangan Non Tunai (BPNT) dengan Menggunakan Metode Weighted Product (Wp)

7. Melakukan perhitungan nilai relatif preferensi vektor $S$

Vektor $S$ dihitung dengan melakukan seluruh perkalian nilai kriteria $\mathrm{C} 1$ hingga $\mathrm{n}$ yang ada pada tabel

3.19 dipangkatkan dengan hasil nilai pangkat ada pada tabel 3.20.

a. $\quad$ Vektor $S$ A1

$S_{1}=\left(\mathrm{C} 1^{\wedge} 0,100\right) *\left(\mathrm{C} 2^{\wedge} 0,075\right) *\left(\mathrm{C} 3^{\wedge} 0,125\right) *\left(\mathrm{C} 4^{\wedge}(-0,125)\right) *\left(\mathrm{C} 5^{\wedge}(-0,100)\right) *\left(\mathrm{C} 6^{\wedge} 0,075\right) *$ $\left(\mathrm{C} 7^{\wedge} 0,050\right) *\left(\mathrm{C} 8^{\wedge}(-0,050)\right) *\left(\mathrm{C} 9^{\wedge} 0,050\right) *\left(\mathrm{C} 10^{\wedge} 0,050\right) *\left(\mathrm{C} 11^{\wedge} 0,075\right) *\left(\mathrm{C} 12^{\wedge} 0,075\right) *$ $\left(\mathrm{C} 13^{\wedge} 0,050\right)$

$S_{1}=\left(3^{\wedge} 0,100\right) *\left(2^{\wedge} 0,075\right) *\left(2^{\wedge} 0,125\right) *\left(3^{\wedge}(-0,125)\right) *\left(2^{\wedge}(-0,100)\right) *\left(2^{\wedge} 0,075\right) *\left(1^{\wedge} 0,050\right) *$ $\left(2^{\wedge}(-0,050)\right) *\left(1^{\wedge} 0,050\right) *\left(1^{\wedge} 0,050\right) *\left(1^{\wedge} 0,075\right) *\left(1^{\wedge} 0,075\right) *\left(1^{\wedge} 0,050\right)$

$S_{1}=1,0610$

b. Vektor $S$ A2

$S_{2}=\left(\mathrm{C} 1^{\wedge} 0,100\right) *\left(\mathrm{C} 2^{\wedge} 0,075\right) *\left(\mathrm{C} 3^{\wedge} 0,125\right) *\left(\mathrm{C} 4^{\wedge}(-0,125)\right) *\left(\mathrm{C} 5^{\wedge}(-0,100)\right) *\left(\mathrm{C} 6^{\wedge} 0,075\right) *$ $\left(\mathrm{C} 7^{\wedge} 0,050\right) *\left(\mathrm{C} 8^{\wedge}(-0,050)\right) *\left(\mathrm{C} 9^{\wedge} 0,050\right) *\left(\mathrm{C} 10^{\wedge} 0,050\right) *\left(\mathrm{C} 11^{\wedge} 0,075\right) *\left(\mathrm{C} 12^{\wedge} 0,075\right) *$ $\left(\mathrm{C} 13^{\wedge} 0,050\right)$

$S_{2}=\left(4^{\wedge} 0,100\right) *\left(2^{\wedge} 0,075\right) *\left(1^{\wedge} 0,125\right) *\left(3^{\wedge}(-0,125)\right) *\left(2^{\wedge}(-0,100)\right) *\left(2^{\wedge} 0,075\right) *\left(3^{\wedge} 0,050\right) *$ $\left(1^{\wedge}(-0,050)\right) *\left(2^{\wedge} 0,050\right) *\left(2^{\wedge} 0,050\right) *\left(3^{\wedge} 0,075\right) *\left(1^{\wedge} 0,075\right) *\left(1^{\wedge} 0,050\right)$

$S_{2}=1,2746$

c. Dan seterusnya dari Vektor $S$ A3 sampai A15

Total jumlah vektor $S_{\text {total }}$ adalah 16,5727, nilai tersebut diperoleh dari hasil vektor dari $S_{1}$ sampai $S_{15}$ dijumlahkan keseluruhannya.

8. Melakukan perhitungan nilai relatif preferensi vektor $V$

Vektor $V$ merupakan nilai preferensi relatif yang akan digunakan untuk mencari peringkat dari hasil perhitungan setiap alternatif. Dengan membagi hasil dari setiap perhitungan vektor $S$ data alternatif dari A1 sampai A15 dengan total jumlah vektor $S$. Total perhitungan vektor $V$ harus berjumlah 1 (satu), jika tidak maka perhitungannya ada yang salah.

a. Vektor $V$ A1

Vektor $V_{1}=\left(\frac{S_{1}}{S_{\text {total }}}\right)=\left(\frac{1,0610}{16,5727}\right)=0,0640$

b. Vektor $V$ A2

Vektor $V_{2}=\left(\frac{S_{2}}{s_{\text {total }}}\right)=\left(\frac{1,2746}{16,5727}\right)=0,0769$

c. Vektor $V$ A3

Vektor $V_{3}=\left(\frac{S_{3}}{S_{\text {total }}}\right)=\left(\frac{1,7039}{16,5727}\right)=0,1028$

d. Dan seterusnya dari Vektor $V$ A4 sampai A15

9. Menentukan ranking

Dari hasil perhitungan nilai vektor $V$ sebelumnya dapat diurutkan hasil perankingan dari yang terbesar sampai terkecil, dimana nilai vektor $V$ terbesar merupakan alternatif yang terbaik dari data yang ada dan merupakan alternatif rekomendasi terpilih, sedangkan nilai vektor $V$ terkecil merupakan alternatif terburuk dari data yang ada. Urutan nilai vektor $V$ dari yang terbesar sampai terkecil adalah sebagai berikut :

$\begin{array}{ll}\text { A3 } & =0,1028 \\ \text { A10 } & =0,0976 \\ \text { A14 } & =0,0915 \\ \text { A2 } & =0,0769 \\ \text { A12 } & =0,0658 \\ \text { A1 } & =0,0640 \\ \text { A5 } & =0,0618 \\ \text { A4 } & =0,0614 \\ \text { A8 } & =0,0603 \\ \text { A13 } & =0,0566 \\ \text { A15 } & =0,0553\end{array}$


INDEXIA: Informatic and Computational Intelegent Journal

Arni Ayuning Tyas, Umi Chotijah, Henny Dwi Bhakti — Decision Support System Rekomendasi Penerima Program

Pemerintah Bantuan Pangan Non Tunai (BPNT) dengan Menggunakan Metode Weighted Product (Wp)

$$
\begin{array}{ll}
\text { A9 } & =0,0553 \\
\text { A11 } & =0,0525 \\
\text { A6 } & =0,0525 \\
\text { A9 } & =0,0553
\end{array}
$$

Sehingga 5 (lima) data warga dusun yang paling direkomendasikan sebagai penerima bantuan sosial pemerintah BPNT adalah A3 Makmur, A10 Suriani, A14 Faisol, A2 Hariyadi Santoso dan A12 Toto Suryadi, dengan nilai vektor $V 5$ (lima) terbesar yaitu 0,1028; 0,0976; 0,0915; 0,0769; dan 0,0658.

\section{IMPLEMENTASI DAN PENGUJIAN SISTEM}

\subsection{Halaman Dashboard}

Halaman Dashboard merupakan halaman pertama yang muncul ketika pengguna membuka sistem. Halaman ini berisikan ucapan selamat datang, fungsi login dan menjelaskan judul dari program tersebut. Disajikan pada Gambar 4.1.

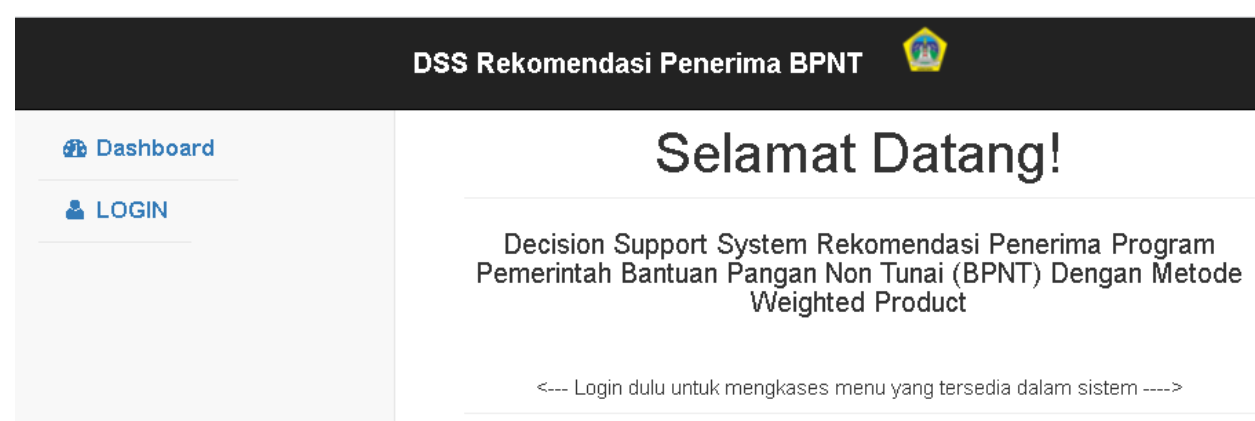

\section{Gambar 4.1 Halaman Dashboard}

\subsection{Hasil Analisa Pengujian Sistem}

Untuk analisa hasil pengujian sistem penulis menggunakan 95 data warga dusun dengan kriteria-kriteria penilaian yang telah ditentukan. Dimana data tersebut didapat dari hasil pengisian angket dan dimasukkan oleh sekretaris desa ke dalam sistem. Pengujian sistem aplikasi Decision Support System (DSS) rekomendasi penerima program pemerintah Bantuan Pangan Non Tunai (BPNT) dengan menggunakan metode Weighted Product (WP) studi kasus pada Dusun Cerme Kidul RT. 001 RW. 001 Cerme, Gresik, proses akhir menghasilkan nilai vektor $\mathrm{V}$ yang dijadikan sebagai dasar pemeringkatan dari yang terbesar ke yang terkecil, data dapat dilihat pada Tabel 4.1.

Tabel 4.1 Tabel Hasil Pemeringkatan Sistem

\begin{tabular}{|c|l|l|l|l|}
\hline \multicolumn{3}{|c|}{ Hasil Akhir Sebelum diurutkan } & \multicolumn{2}{c|}{ Hasil Akhir Sebelum diurutkan } \\
\hline NO & NAMA & \multicolumn{1}{c|}{ VEKTOR V } & NAMA & VEKTOR V \\
\hline 1 & Hariyanto & 0.0096137443255736 & Karpi & 0.016168326281081 \\
\hline 2 & $\begin{array}{l}\text { Hariyadi } \\
\text { Santoso }\end{array}$ & 0.011549211866708 & Sutiyo & 0.01568936435684 \\
\hline 3 & Makmur & 0.015439934059181 & Sujiani & 0.015617573732807 \\
\hline 4 & $\begin{array}{l}\text { M. Ilham } \\
\text { Ghozali }\end{array}$ & 0.0092197171968844 & Makmur & 0.015439934059181 \\
\hline 5 & $\begin{array}{l}\text { Mohamad } \\
\text { Dirham }\end{array}$ & 0.0092862649010666 & Jumiatun & 0.01528421575844 \\
\hline 6 & Ribut & 0.0078883441718546 & Suriani & 0.014657779747079 \\
\hline 7 & $\begin{array}{l}\text { Satria Rio } \\
\text { D. }\end{array}$ & 0.006826879315764 & Legiyo & 0.014571711540467 \\
\hline 8 & Sarwi & 0.0090613279738599 & Antimah & 0.014382337336784 \\
\hline 9 & Sugiantoro & 0.0083092743888331 & Agus & 0.014158481959082 \\
\hline 10 & Suriani & 0.014657779747079 & Kacung & 0.014080114746284 \\
\hline 11 & Suroso & 0.0078883441718546 & Sikan & 0.014075345551551 \\
\hline 12 & $\begin{array}{l}\text { Toto } \\
\text { Suryadi }\end{array}$ & 0.0098814482237102 & Sidik & 0.013897129342651 \\
\hline
\end{tabular}


INDEXIA: Informatic and Computational Intelegent Journal

Arni Ayuning Tyas, Umi Chotijah, Henny Dwi Bhakti — Decision Support System Rekomendasi Penerima Program

Pemerintah Bantuan Pangan Non Tunai (BPNT) dengan Menggunakan Metode Weighted Product (Wp)

\begin{tabular}{|c|c|c|c|c|}
\hline 13 & $\begin{array}{l}\text { Tri } \\
\text { Hartanto }\end{array}$ & 0.0085044547846685 & Faisol & 0.013734404924564 \\
\hline 14 & Faisol & 0.013734404924564 & Suud & 0.013676192086704 \\
\hline 15 & Salehudin & 0.0083092743888331 & Puji & 0.013658384978605 \\
\hline 16 & Sudar & 0.0077528271405131 & Sujito & 0.013595887610414 \\
\hline 17 & Ibrahim & 0.0093808750147598 & Sutaji & 0.013210330777902 \\
\hline 18 & Darmaji & 0.010712521898817 & Toha & 0.013098584963814 \\
\hline 19 & $\begin{array}{l}\text { Adi } \\
\text { Prasetyo }\end{array}$ & 0.011886287267786 & $\begin{array}{l}\text { Totok } \\
\text { Hariaydi }\end{array}$ & 0.012524794249027 \\
\hline 20 & $\begin{array}{l}\text { Abdul } \\
\text { Ghofur }\end{array}$ & 0.0095011749659275 & Sukirno & 0.012237345569343 \\
\hline 21 & Dedik R. & 0.0087526658782542 & Susanto & 0.011905816724826 \\
\hline 22 & Sutiyo & 0.01568936435684 & Adi Prasetyo & 0.011886287267786 \\
\hline 23 & Sutrisno & 0.011090298167728 & Soni & 0.011617427597605 \\
\hline 24 & Sutaji & 0.013210330777902 & $\begin{array}{l}\text { Hariyadi } \\
\text { Santoso }\end{array}$ & 0.011549211866708 \\
\hline 25 & Kacuk & 0.0089582613022095 & Darto & 0.011549211866708 \\
\hline 26 & Jarot & 0.0087526658782542 & Zakky & 0.011254787195606 \\
\hline 27 & Iqbal & 0.0094362834056495 & Nur Khojim & 0.01122169536518 \\
\hline 28 & Darto & 0.011549211866708 & Sukadi & 0.01122169536518 \\
\hline 29 & $\begin{array}{l}\text { Ali } \\
\text { Murtado }\end{array}$ & 0.0099398132637384 & Maskan & 2169536518 \\
\hline 30 & Abu Hasan & 0.010008167504898 & Dhofir & 0.01120708413852 \\
\hline 31 & Antimah & 0.014382337336784 & Sutrisno & 0.011090298167728 \\
\hline 32 & $\begin{array}{l}\text { Emi } \\
\text { Kumala }\end{array}$ & 0.0084545179467466 & $\mathrm{n}$ & 0.010978447794614 \\
\hline 33 & Sarim & 0.010978447794614 & Darmaji & 0.010712521898817 \\
\hline 34 & Soni & 0.011617427597605 & Ma'fud & 0.010698573642295 \\
\hline 35 & Zakky & 0.011254787195606 & Aan Eko W. & 0.010545785743237 \\
\hline 36 & Karpi & 0.016168326281081 & & 0.010528487184525 \\
\hline 37 & $\begin{array}{l}\text { Tina } \\
\text { Prasetyo } \\
\end{array}$ & 0.0089056597828838 & Edy K. & 0.010501087766227 \\
\hline 38 & Anang & 0.0089056597828838 & Septin & 0.010497530853988 \\
\hline 39 & $\begin{array}{l}\text { Slamet } \\
\text { Riyadi }\end{array}$ & 0.0085044547846685 & Ande & 0.010470211996689 \\
\hline 40 & Suwitno & 0.0092348654148994 & $\begin{array}{l}\text { Sholikin } \\
\text { Sumi }\end{array}$ & 0.010439427009475 \\
\hline 41 & Edy & 0.0096137443255736 & Marjuki & 0.010422302914083 \\
\hline 42 & Maskan & 0.01122169536518 & Sutrisno Is & 0.010083821801611 \\
\hline 43 & Puji & 0.013658384978605 & Abu Hasan & 0.010008167504898 \\
\hline 44 & Marjuki & 0.010422302914083 & Ali Murtado & 0.0099398132637384 \\
\hline 45 & Legiyo & 1540467 & Toto Suryadi & 98814482237102 \\
\hline 46 & Kuswandi & 0.0096137443255736 & Alfian & 0.00972435246663 \\
\hline 47 & Suyono & 0.0087526658782542 & Hariyanto & 0.0096137443255736 \\
\hline 48 & Suud & 0.013676192086704 & Edy & 0.0096137443255736 \\
\hline 49 & Sutarno & 0.0096012267341739 & Kusu & 0.0096137443255736 \\
\hline 50 & $\begin{array}{l}\text { Khoirul } \\
\text { Anam }\end{array}$ & 0.0089056597828838 & Grisandi & 0.0096137443255736 \\
\hline 51 & Kacung & 0.014080114746284 & Sutarno & 0.0096012267341739 \\
\hline 52 & Hadi & 0.0093808750147598 & Supri & 0.0096012267341739 \\
\hline 53 & Grisandi & 0.0096137443255736 & & 0.0095448498216716 \\
\hline 54 & Ariska & 0.0086023003173324 & $\begin{array}{l}\text { Abdul } \\
\text { Ghofur }\end{array}$ & 0.0095011749659275 \\
\hline 55 & Abu Amar & 0.0089056597828838 & Iqbal & 0.0094362834056495 \\
\hline 56 & $\begin{array}{l}\text { Adi } \\
\text { Mulyono }\end{array}$ & 0.0091148489515475 & Hadi & 0.0093808750147598 \\
\hline
\end{tabular}


INDEXIA: Informatic and Computational Intelegent Journal

Arni Ayuning Tyas, Umi Chotijah, Henny Dwi Bhakti — Decision Support System Rekomendasi Penerima Program

Pemerintah Bantuan Pangan Non Tunai (BPNT) dengan Menggunakan Metode Weighted Product (Wp)

\begin{tabular}{|c|c|c|c|c|}
\hline 57 & Agus & 0.014158481959082 & Ibrahim & 0.0093808750147598 \\
\hline 58 & Nanang & 0.0091267324283161 & Dadang & 0.0093808750147598 \\
\hline 59 & Slamet V. & 0.0086023003173324 & Firman & 0.009337950466896 \\
\hline 60 & Sukirno & 0.012237345569343 & $\begin{array}{l}\text { Mohamad } \\
\text { Dirham }\end{array}$ & 0.0092862649010666 \\
\hline 61 & Dhofir & 0.01120708413852 & Puryono & 0.0092862649010666 \\
\hline 62 & Alfian & 0.00972435246663 & Suwitno & 0.0092348654148994 \\
\hline 63 & $\begin{array}{l}\text { Totok } \\
\text { Hariaydi }\end{array}$ & 0.012524794249027 & Indra & 0.0092317373955409 \\
\hline 64 & Indra & 0.0092317373955409 & $\begin{array}{l}\text { M. Ilham } \\
\text { Ghozali }\end{array}$ & 0.0092197171968844 \\
\hline 65 & Abdul Muis & 0.0083092743888331 & Nanang & 0.0091267324283161 \\
\hline 66 & Sikan & 0.014075345551551 & $\begin{array}{l}\text { Adi } \\
\text { Mulyono }\end{array}$ & 0.0091148489515475 \\
\hline 67 & Sidik & 0.013897129342651 & Sarwi & 0.0090613279738599 \\
\hline 68 & Toha & 0.013098584963814 & Sugik & 0.0090613279738599 \\
\hline 69 & Candra W. & 0.0087526658782542 & Kacuk & 0.0089582613022095 \\
\hline 70 & Susanto & 0.011905816724826 & Abu Amar & 0.0089056597828838 \\
\hline 71 & $\begin{array}{l}\text { Aan Eko } \\
\text { W. }\end{array}$ & 0.010545785743237 & $\begin{array}{l}\text { Tina } \\
\text { Prasetyo }\end{array}$ & 0.0089056597828838 \\
\hline 72 & Sutrisno Is & 0.01008382 & Anang & 0.0089056597828838 \\
\hline 73 & $\begin{array}{l}\text { Nurul } \\
\text { Efendi }\end{array}$ & 17689 & $\begin{array}{l}\text { Khoirul } \\
\text { Anam }\end{array}$ & 0.0089056597828838 \\
\hline 74 & Delan & 879 & Mariyan & 28838 \\
\hline 75 & Dada & 47598 & Sentot & 15116 \\
\hline 76 & Nur Khojim & 0.0112216 & Dedik R. & 0.0087526658782542 \\
\hline 77 & Puryono & 0.0092862649010666 & Jarot & 0.0087526658782542 \\
\hline 78 & Sentot & 0.0088533671315116 & Suyono & 0.0087526658782542 \\
\hline 79 & Sugik & 0.0090613279738599 & Candra W. & 0.0087526658782542 \\
\hline 80 & Suharton & 0.0095448498216716 & Turmudji & 0.0087526658782542 \\
\hline 81 & Sukadi & 0.01122169536518 & & 0.0086023003173324 \\
\hline 82 & Sulis & 0.0081665260283097 & Sla & 0.0086023003173324 \\
\hline 83 & Suparman & 525 & Tri Hartanto & 77846685 \\
\hline 84 & Supri & 0.0096012267341739 & $\begin{array}{l}\text { Slamet } \\
\text { Riyadi }\end{array}$ & 47846685 \\
\hline 85 & Turmudji & 0.0087526658782542 & Emi Kumala & 0.0084545179467466 \\
\hline 86 & Jumiatun & 0.01528421575844 & Nurul Efendi & 0.0083583533417689 \\
\hline 87 & Ande & 0.010470211996689 & Sugiantoro & 0.0083092743888331 \\
\hline 88 & Firman & 0.009337950466896 & Salehudin & 0.0083092743888331 \\
\hline 89 & Mariyanto & 0.0089056597828838 & Abdul Muis & 0.0083092743888331 \\
\hline 90 & Ma'fud & 0.010698573642295 & Delan & 0.0082604836198879 \\
\hline 91 & Sujito & 0.013595887610414 & & 0.0081665260283097 \\
\hline 92 & Septin & & $\mathrm{Ri}$ & 0.0078883441718546 \\
\hline 93 & Sujiani & 0.015617573732807 & Suroso & 0.0078883441718546 \\
\hline 94 & Edy K. & 0.010501087766227 & Sudar & 0.0077528271405131 \\
\hline 95 & $\begin{array}{l}\text { Sholikin } \\
\text { Sumi }\end{array}$ & 0.010439427009475 & Rio D. & 0.006826879315764 \\
\hline \multicolumn{2}{|r|}{ TOTAL } & 1.00 & TOTAL & 1.00 \\
\hline
\end{tabular}

\section{PENUTUP}

\subsection{Kesimpulan}

Berdasarkan penelitian dengan judul Decision Support System (DSS) rekomendasi penerima program pemerintah Bantuan Pangan Non Tunai (BPNT) dengan menggunakan metode Weighted Product (WP) studi kasus pada Dusun Cerme Kidul RT. 001 RW. 001 Cerme, Gresik, maka dapat diambil kesimpulan bahwa sistem dapat membantu sekretaris desa dalam merekomendasikan warga dusun sebagai penerima program pemerintah bantuan pangan non tunai yang berhak secara cepat dan lebih tepat sasaran. 
INDEXIA: Informatic and Computational Intelegent Journal

Arni Ayuning Tyas, Umi Chotijah, Henny Dwi Bhakti — Decision Support System Rekomendasi Penerima Program

Pemerintah Bantuan Pangan Non Tunai (BPNT) dengan Menggunakan Metode Weighted Product (Wp)

\subsection{Saran}

Adapun saran yang dapat diberikan kepada penelitian berikutnya apabila ingin mengembangkan sistem pendukung keputusan yang telah dibuat ini agar menjadi lebih baik adalah :

1. Sistem dapat dikembangkan lebih lanjut untuk permasalahan lain, bahkan yang lebih komplek dengan jumlah kriteria lebih banyak.

2. Mengembangkan sistem dengan menambahkan menu halaman dan fitur-fitur yang lebih lengkap sesuai dengan kebutuhan.

3. Diharapkan pengembangan selanjutnya menggunakan metode lain untuk hasil yang lebih baik.

\section{DAFTAR PUSTAKA}

[1] Aliy Hafiz, M. M. (2018). Sistem Pendukung Keputusan Pemilihan Karyawan Terbaik Dengan Pendekatan Weighted Product (Studi Kasus:Pt. Telkom Cab. Lampung). Jurnal Cendikia, 23-28.

[2] Dyna Marisa Khairina, D. I. (2016). Implementasi Metode Weighted Product Untuk Aplikasi Pemilihan Smartphone Android. Jurnal Infotel Vol. 8 No.1, 16-23.

[3] Hindayati Mustafidah, H. N. (2017). Sistem Pendukung Keputusan Penentuan Mahasiswa Berprestasi Di Universitas Muhammadiyah Purwokerto Menggunakan Metode Weighted Product (Wp) . Juita, 51-61.

[4] Irwan. (2019, 08 09). Bantuan Pangan Non Tunai (Bpnt). Retrieved From Pusdatin Kemensos: Https://Pusdatin.Kemensos.Go.Id/Bantuan-Pangan-Non-Tunai-Bpnt

[5] Kunti Eliyen, F. S. (2019). Implementasi Metode Weighted Product Untuk Penentuan Mustahiq Zakat. Infotekjar : Jurnal Nasional Informatika Dan Teknologi Jaringan, 146-150.

[6] Moch Rosid Noviansyah, W. S. (2019). Sistem Pendukung Keputusan Pemilihan Laptop Pada E-Commerce Menggunakan Metode Weighted Product. Seminar Nasional Teknologi Dan Rekayasa (Sentra), 43-53.

[7] Muhammad Anwar Saputera, A. T. (2017). Sistem Pendukung Keputusan Penentuan Penerima Program Bantuan Daerah Menggunakan Weighted Product. Prosiding Seminar Ilmu Komputer Dan Teknologi Informasi, 76-80.

[8] Oktavia, P. (2018). Sistem Pendukung Keputusan Seleksi Penerima Beasiswa Dengan Metode Weighted Product Pada Smp Negeri 1 Parung Berbasis Web. Jurnal Informatika Universitas Pamulang, 80-86.

[9] Sari, N. (2018). [Skripsi] Sistem Pendukung Keputusan Pemilihan Smartphone Dengan Metode Weighted Product. Program Studi Teknik Informatika Tangerang.

[10] Tim Pengendali Pelaksanaan Penyaluran Bantuan Sosial Secara Non. (2019, 09). Pedoman Umum Bantuan Pangan Nontunai 2019. Retrieved From Kementrian Sosial: Https://Kemensos.Go.Id

[11]Yunus, E. Y. (2019). Implementasi Program Bantuan Pangan Non Tunai (Bpnt) Di Kecamatan Kanigaran Kota Probolinggo. Issn 2088-7469 Volume 9 Nomor 2, 138-152. 